DOI: $10.17516 / 1997-1389-0310$

УДК 597.5; 574.52

\title{
Distribution of Metals in Red and White Axial Muscles of Three Fish Species from the Krasnoyarsk Reservoir
}

\author{
Nikita O. Yablokov*a,b, \\ Olesya V. Anishchenko ${ }^{c}$ and Ivan V. Zuev ${ }^{a}$ \\ ${ }^{a}$ Siberian Federal University \\ 79 Svobodny, Krasnoyarsk, 660041, Russia \\ ${ }^{b}$ Krasnoyarsk Branch of the FSBSI "VNIRO" \\ 33 Parizhskoj Kommuny, Krasnoyarsk, 660049, Russia \\ "Institute of Biophysics SB RAS \\ $F R C$ "Krasnoyarsk Science Center SB RAS" \\ 50/50 Akademgorodok, Krasnoyarsk, 660036, Russia
}

Received 14.05.2019, received in revised form 31.07.2019, accepted 03.09.2019

The content of metals in fish fillet is an important criterion for food safety and nutritional benefits. Fish fillet is composed of both white and red muscles, but the standard method only detects metal content in white muscle. The true metal content in fish fillet can be underestimated due to this approach. So far, metal content in different types of muscle tissue of freshwater fish remains virtually unstudied. The aim of the present research was to study the metal content in red and white muscles of roach Rutilus rutilus, bream Abramis brama and pike Esox lucius that live in the Krasnoyarsk reservoir. Twenty metals were measured in the dry mass of red and white muscles of three fish species using inductively coupled plasma (ICP-OES) spectrometry. The contents of macronutrients such as $\mathrm{K}, \mathrm{Ca}$ and $\mathrm{Mg}$ were higher in white muscle fibers and $\mathrm{Na}$-in red fibers. Of the 16 metals regarded as trace elements, the highest contents in the muscles were noted for Fe (20.5-177.8 $\mu \mathrm{g} / \mathrm{g}), \mathrm{Zn}(26.7-79.0 \mu \mathrm{g} / \mathrm{g})$, and Al (15.2$67.2 \mu \mathrm{g} / \mathrm{g})$, regardless of the fish species and type of tissue. $\mathrm{Li}(0.01-0.09 \mu \mathrm{g} / \mathrm{g})$ and Cd (0.01-0.03 $\mu \mathrm{g} / \mathrm{g})$ had the lowest concentrations. Among trace elements, the contents of $\mathrm{Cu}$ and $\mathrm{Fe}$ were significantly higher in the dry biomass of red muscle compared with white muscle for the three fish species. The content of Zn was higher in the red muscle of bream and pike. Almost all other trace elements also tended to accumulate in higher concentrations in the red muscle. Differences between red and white muscles in the contents of trace elements such as $\mathrm{Pb}$ and $\mathrm{Sr}$ were species-specific. The distribution of metals between the two types of muscle fibers demonstrated by the freshwater species examined in this

(C) Siberian Federal University. All rights reserved

This work is licensed under a Creative Commons Attribution-NonCommercial 4.0 International License (CC BY-NC 4.0).

* Corresponding author E-mail address: noyablokov@mail.ru 
study was similar to the distribution of metals in marine fish, except the distribution of Sr. Thus, the greater capacity of the red muscle for accumulating most heavy metals confirmed in the present study may indicate a greater risk to health in eating this type of tissue.

Keywords: heavy metals, macronutrients, trace elements, axial muscles, roach, bream, pike, ICP-OES spectrometry.

Citation: Yablokov N.O., Anishchenko O.V., Zuev I.V. Distribution of metals in red and white axial muscles of three fish species from the Krasnoyarsk reservoir. J. Sib. Fed. Univ. Biol., 2019, 12(4), 430-444. DOI: 10.17516/1997-1389-0310.

\title{
Распределение металлов в красной \\ и белой осевой мускулатуре \\ трех видов рыб Красноярского водохранилища
}

\author{
Н.О. Яблоков ${ }^{\mathrm{a}, \tilde{0}}$, О.В. Анищенков ${ }^{\mathrm{B}}$ И.В. Зуев ${ }^{\mathrm{a}}$ \\ ${ }^{a}$ Сибирский федеральный университет \\ Россия, 660041, Красноярск, пр. Свободный, 79 \\ ${ }^{6}$ Красноярский филиал ФГБНУ «ВНИРО» \\ Россия, 660049, Красноярск, ул. Парижской Коммуны, 33 \\ ${ }^{6}$ Институт биофизики СО РАН \\ ФИЦ «Красноярский научный иентр СО РАН» \\ Россия, 660036, Красноярск, Академгородок, 50/50
}

Содержание металлов в филе рыб - важный показатель пользы и безопасности его употребления впищу. Потребляемое филерыбвключаеткакбелую, такикраснуюмускулатуру, тогда как стандартный метод нацелен на определение содержания металлов лишь в белой мускулатуре. Такой подход может приводить к недооценке истинного содержания металлов в филе рыб. Содержание металлов в разных типах мымечной ткани пресноводных рыб в настоящее время практически не изучено. Целью работы являлось исследование содержания металлов в красных и бельх мышиах плотвы Rutilus rutilus, леща Abramis brama и щуки Esox lucius, обитающих в Красноярском водохранилище. С помощьюю метода атомно-эмиссионной спектрометрии с индуктивно-связанной плазмой (ИСП-АЭС) определено содержание 20 металлов в сухой массе красной и белой мускулатуры рыб. Макроэлементы $\mathrm{K}$, Са и $\mathrm{Mg}$ в большей степени накапливались в белых мышечных волокнах, $\mathrm{Na}$ - в красных. Среди 16 металлов, относимых к микроэлементам, доминантами по уровню содержания в мышиах, вне зависимости от вида рыбы и типа ткани, выступили Fe (20,5-177,8 мкг/2), Zn (26,7-79,0 мкг/2) и Al (15,2-67,2 мкг/2). Наименьшими значениями концентращий характеризовались Li (0,01-0,09 мкг/2) и Cd (0,01-0,03 мкг/2). Среди микроэлементов содержание Cи и Fе было достоверно выше в сухой биомассе красных мыши по сравнению с белыми для всех трех видов рыб, а содержание Zn - для леща и щуки. Практически все остальные микроэлементы также 
проявили тенденциюю накаливаться в большей степени в красной мускулатуре. Различия между красными и бельми мыщцами в содержании таких микроэлементов, как $\mathrm{Pb} u \mathrm{Sr}$, были видоспецифичны. Исследованные пресноводные виды в целом демонстрировали сходные с морскими рыбами закономерности распределения металлов по типам мымечных волокон за исключением распределения Sr. Таким образом, подтвержденное свойство красных мыши к интенсивному накоплению больиинства тяжельх металлов может свидетельствовать о большем риске потребления этого вида ткани в пищу.

Ключевые слова: тяжелье металль, макроэлементы, микроэлементы, осевая мускулатура, плотва, лещ, щука, ИСП-спектрометрия.

Цитирование: Яблоков, Н.О. Распределение металлов в красной и белой осевой мускулатуре трех видов рыб Красноярского водохранилища / Н.О. Яблоков, О.В. Анищенко, И.В. Зуев // Журн. Сиб. федер. ун-т. Биология, 2019. 12(4). C. 430-444. DOI: $10.17516 / 1997-1389-0310$

\section{Введение}

Осевая мускулатура большинства видов рыб дифференцирована на слои белой и красной ткани, различные в структурном и функциональном отношении (Moyle et al., 2004). Питание красных мышц происходит за счет окислительного фосфорилирования, в то время как белые мышцы получают энергию за счет анаэробных процессов (Svendsen et al., 2015). Как следствие, мышцы с аэробным питанием используются рыбой для продолжительного плавания, анаэробные - для кратковременных мощных ускорений (Sanger, Stoiber, 2001).

В ходе сравнительных исследований красной и белой мускулатуры рыб были выявлены многочисленные различия в их морфологии, гистологии, физиологии и биохимии (Bone, 1978; Johnston, 1981; Luther et al., 1995; Sanger, Stoiber, 2001). Неоднородное распределение различных химических элементов также отражает специфику указанных типов ткани. Наибольший интерес при оценке химического состава мышечной ткани рыб представляют микро- и макроэлементы, имеющие металлическую природу, так как в зависимости от концентрации дан- ная группа элементов может как способствовать нормальному развитию и жизнедеятельности рыбы, так и оказывать токсическое воздействие (Golovanova, 2008). В первую очередь это касается тяжелых металлов, накапливающихся в мышцах промысловых рыб. Следует отметить, что для человека пищевую ценность имеет мышечная ткань в целом, однако большинство исследований химического состава рыбной продукции основано на оценке содержания металлов в белой мускулатуре как основной части потребляемого в пищу филе рыбы (Cronin et al., 1998; Kojadinovic et al., 2007). Вследствие различий в физиолого-биохимических процессах красная мускулатура может более интенсивно накапливать отдельные тяжелые металлы, что потенциально создает риск недооценки истинного содержания тех или иных элементов в потребляемом филе промысловых рыб (Bosch et al., 2016a, 2016b).

К настоящему времени получены данные о различиях в накоплении и утилизации металлов красными и белыми мышцами для большого количества морских видов рыб, составляющих основу мирового промысла (Caprene et al., 1990; Karunarathna, Attygalle, 
2009; Ashoka et al., 2011; Albrecht-Ruiz, SalasMaldonado, 2015). Пресноводные рыбы в этом отношении изучены слабо. Единичные сведения приведены по клариевому сому Clarias macrocephalus Gunter, 1864 и черному конгрио Genypterus blacodes (Forster, 1801) (Ashoka et al., 2011; Chaijan et al., 2013); также имеются данные о распределении некоторых металлов для ряда пресноводных видов рыб, выращиваемых в условиях аквакультуры (Caprene et al., 1990, 1998).

Очевидно, что закономерности распределения металлов по типу мышечных тканей, выявленные для морских рыб, невозможно прямо интерполировать на пресноводные виды. Ряд работ указывает на различия в содержании железа, цинка, кадмия, ртути и других металлов в мускулатуре морских, полупроходных и пресноводных видов рыб (Parks, Rose, 1933; Патин, Морозов, 1981; Cheung et al., 2008; Марченко и др., 2006). Таким образом, сравнительные исследования содержания металлов в красных и белых мышцах пресноводных рыб необходимы для более полного понимания различий в функционировании данных типов тканей. Содержание металлов в рыбе зависит от их физиологической роли, а также от концентрации во внешней среде (пище, воде). В настоящее время к эссенциальным, или биологически важным, для рыб металлам, кроме макроэлементов (калий (K), натрий (Na), кальций (Ca), магний $(\mathrm{Mg}))$, относят микроэлементы - железо (Fe), медь $(\mathrm{Cu})$, цинк $(\mathrm{Zn})$, марганец $(\mathrm{Mn})$, никель $(\mathrm{Ni})$, кобальт (Co), молибден (Mo), хром (Cr), ванадий (V), селен (Se), к неэссенциальным серебро (Ag), алюминий (Al), ртуть (Hg), мышьяк (As), стронций (Sr), уран (U), свинец (Pb) и кадмий (Cd) (Wood et al., 2012a, 2012b). Роль остальных элементов, включая литий (Li) и титан (Ti), до конца не определена (Peña-Icart et al., 2017).
Целью работы являлось исследование содержания металлов в красных и белых мышцах плотвы Rutilus rutilus (Linnaeus, 1758), леща Abramis brama L., 1758 и щуки Esox lucius L., 1758, обитающих в заливе Убей Красноярского водохранилища. Была поставлена задача по выявлению различий в распределении ряда металлов - макроэлементов $(\mathrm{Na}, \mathrm{K}, \mathrm{Ca}, \mathrm{Mg}$ ) и микроэлементов ( $\mathrm{Fe}, \mathrm{Cu}, \mathrm{Zn}$, Mn, Ni, Co, Mo, Cr, Al, Sr, Pb, Cd, Bi, Ga, Li, Ti) между двумя типами мышечной ткани рыб из пресноводного водохранилища.

\section{Материалы и методы}

Ихтиологический материал был собран в июне 2016 г. в заливе Убей Красноярского

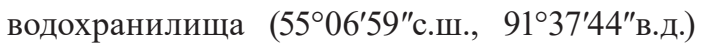
(Красноярское водохранилище..., 2008). Данный участок не имеет точечных источников загрязнения тяжелыми металлами и может рассматриваться в качестве фонового. Отлов рыб производили набором жаберных сетей с размером ячеи 30-70 мм (разрешение на вылов (добычу) водных биологических ресурсов № 242016 030454). Объектами исследования служили три массовых промысловых вида рыб: плотва, лещ и щука. После поимки рыб усыпляли в емкости, содержащей водную эмульсию гвоздичного масла (Underwood et al., 2013). Измеряли абсолютную длину тела (TL, Mм), массу (W, г), снимали чешую для последующего определения возраста (табл. 1). C каждой рыбы пластиковым ножом отбирали пробы мышечной ткани двух типов: белую мускулатуру - из эпаксиальных миомеров в районе спинного плавника; красную мускулатуру - латеральный пласт мышц между эпаксиальными и гипоксиальными миомерами вдоль всего тела (Bosch et al., 2016b) (рис. 1). Сырая масса образцов мускулатуры варьировала в пределах 3-5 г. Пробы помещали в герметичные пластиковые контейнеры и 
Таблица 1. Биометрические параметры исследованных рыб

Table 1. Biometric parameters of the fishes

\begin{tabular}{|c|c|c|c|c|c|c|}
\hline \multirow{2}{*}{ Вид } & \multicolumn{2}{|c|}{ TL, мм } & \multicolumn{2}{|c|}{$\mathrm{W}, \Gamma$} & \multirow{2}{*}{ Возраст, лет } & \multirow{2}{*}{$\mathrm{N}$, экз. } \\
\hline & $\min -\max$ & $\mathrm{X} \pm \mathrm{SE}$ & $\min -\max$ & $\mathrm{X} \pm \mathrm{SE}$ & & \\
\hline Плотва & $214-245$ & $229,8 \pm 5,8$ & $130-145$ & $137,4 \pm 2,6$ & 4 & 5 \\
\hline Щука & $420-560$ & $488,0 \pm 23,1$ & $751-811$ & $782,8 \pm 10,8$ & 4 & 5 \\
\hline Лещ & $200-290$ & $222,0 \pm 17,4$ & $190-263$ & $236,6 \pm 12,9$ & 4 & 5 \\
\hline
\end{tabular}

Примечание: TL - абсолютная длина тела, W - масса тела.

(a)

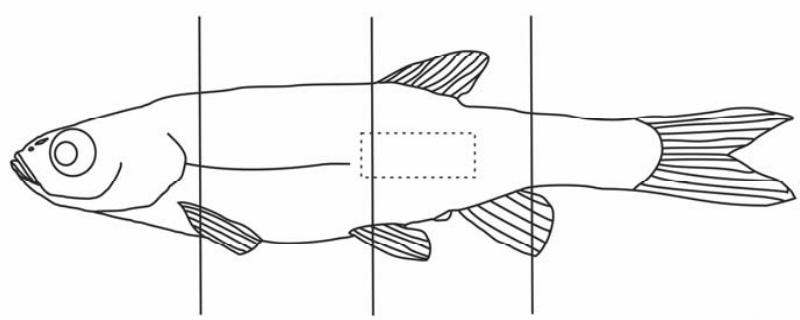

(a)

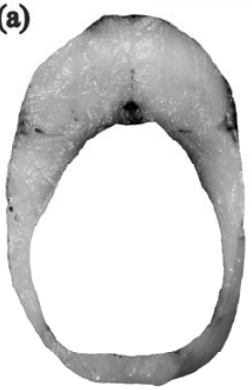

(๘)

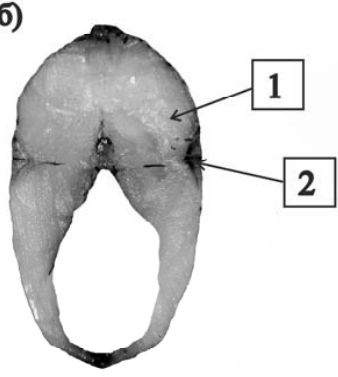

(B)

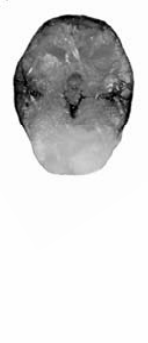

Рис. 1. Распределение белой (1) и красной (2) мышечной ткани в различных участках тела рыбы: а - район грудных плавников; б - район спинного плавника; в - район анального плавника. Пунктиром отмечен участок отбора образцов мышечной ткани

Fig. 1. Distribution of white (1) and red (2) muscle types in the axial musculature in three body regions: a pectoral fin region; 6 - dorsal fin region; в - anal fin region. The dotted line marks the sampling site

замораживали. С каждой рыбы были взяты по одной пробе красной и белой мускулатуры, всего исследовано по пять экземпляров каждого вида рыб.

В лабораторных условиях пробы предварительно высушивали до постоянной массы при температуре $105^{\circ} \mathrm{C}$, затем измельчали до однородной консистенции в агатовой ступке. Навеску 0,2 г сухих мышц озоляли в 3 мл смеси азотной и хлорной кислот $\left(\mathrm{HNO}_{3}: \mathrm{HClO}_{4}\right.$, $1: 1)$ нагреванием на лабораторной плитке и упариванием до влажных солей. Озоленные пробы переносили в полипропиленовые пробирки и добавляли 14 мл деионизированной воды (18 МОм) с последующим разведением еще в 5-7 раз, т.е. минерализованные образцы разбавляли до 70-98 мл деионизированной водой. Определение содержания элементов проводили с помощью эмиссионного спектрометра с индуктивно-связанной плазмой (ИСП) iCAP 6300 Duo (ThermoScientific, Великобритания). В качестве внутреннего стандар- 
та использовали раствор Sc (5 мг/л, Scandium Standard for ICP, Fluka, Швейцария). Калибровочные растворы готовили разведением мультиэлементных стандартов «ICP multi-elements solutions» IV и XVI фирмы Merck (Германия). Анализ включал также измерение холостых проб, выпаренных на плитке и разведенных в том же объеме воды, что и анализируемые пробы. Подробное описание методики анализа и условий измерения приведены в работе (Anishchenko et al., 2017). Контроль качества анализа осуществляли путем измерения стандартного образца состава мышечной ткани байкальского окуня (Бок-2, ГСО № 90552008 , Институт геохимии им. Виноградова, Иркутск). Было определено содержание 20 металлов - $\mathrm{Na}, \mathrm{K}, \mathrm{Ca}, \mathrm{Mg}, \mathrm{Al}, \mathrm{Bi}, \mathrm{Cd}, \mathrm{Co}, \mathrm{Cr}$, $\mathrm{Cu}, \mathrm{Fe}, \mathrm{Ga}, \mathrm{Li}, \mathrm{Mn}, \mathrm{Mo}, \mathrm{Ni}, \mathrm{Pb}, \mathrm{Sr}, \mathrm{Ti}, \mathrm{Zn}$.

Для полученных значений содержания металлов (мкг/г сухой массы) в двух типах мышечной ткани рассчитывали среднее арифметическое $(\mathrm{X})$ и стандартную ошибку (SE). Поскольку тип распределения содержания металлов во многих случаях отличался от нормального (по критерию Шапиро-Уилка), сравнение средних значений концентраций металлов в красной и белой мускулату- ре для каждого вида проводили с помощью U-критерия Манна-Уитни. Все статистические расчеты выполнены в программе PAST 3.24 (Hammer et al., 2001).

\section{Результаты}

Общей чертой распределения металлов в мышечной ткани исследованных видов явилось существенное преобладание металловмакроэлементов, среди которых во всех случаях доминировал $\mathrm{K}$, превышая содержание других элементов на порядок и более (табл. 2, рис. 2). Позиции прочих макроэлементов $\mathrm{Ca}, \mathrm{Na}$ и $\mathrm{Mg}$ - варьировали в зависимости от вида рыбы и типа тканей. Среди металловмикроэлементов наибольшим содержанием характеризовались Fe, $\mathrm{Zn}$ и Al. Далее в том или ином порядке следовали $\mathrm{Cu}, \mathrm{Ti}, \mathrm{Mn}$ и $\mathrm{Sr}$. Наименьшие концентрации в сухой массе мышц отмечены для лития и кадмия. Исключение составили ткани белой мускулатуры леща, в которых минимальное содержание было характерно для свинца и кобальта (рис. 2).

Статистически значимые различия ( $<<0,05 ;$ U-критерий Манна-Уитни) между красными и белыми мышцами выявлены для 11 из 20 исследованных металлов (табл. 2).

\section{Плотва, белые мышщы \\ \begin{tabular}{lllllllllllllllllllllll}
\hline & $\mathrm{Ca}$ & $\mathrm{Na}$ & $\mathrm{Mg}$ & $\mathrm{Zn}$ & $\mathrm{Fe}$ & $\mathrm{Al}$ & $\mathrm{Sr}$ & $\mathrm{Ti}$ & $\mathrm{Mn}$ & $\mathrm{Cu}$ & $\mathrm{Cr}$ & $\mathrm{Pb}$ & $\mathrm{Ni}$ & $\mathrm{Ga}$ & $\mathrm{Mo}$ & $\mathrm{Co}$ & $\mathrm{Li}$ & $\mathrm{Cd}$ & $\mathrm{Bi}^{*}$
\end{tabular} Плотва, красные мышщы

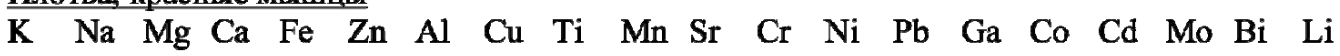 Лещ, белые мышщы

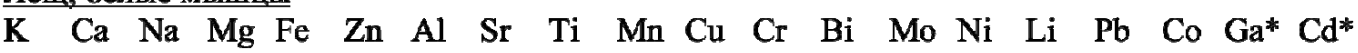 Дещ, красные мышшы

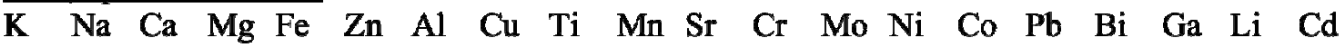 Шука, белые мышщы \\ $\begin{array}{lllllllllllllllllllllll}\mathrm{K} & \mathrm{Na} & \mathrm{Mg} & \mathrm{Ca} & \mathrm{Fe} & \mathrm{Zn} & \mathrm{Al} & \mathrm{Ti} & \mathrm{Cu} & \mathrm{Mn} & \mathrm{Sr} & \mathrm{Cr} & \mathrm{Pb} & \mathrm{Mo} & \mathrm{Ni} & \mathrm{Bi} & \mathrm{Ga} & \mathrm{Co} & \mathrm{Li} & \mathrm{Cd}\end{array}$ Щука, красные мышщы

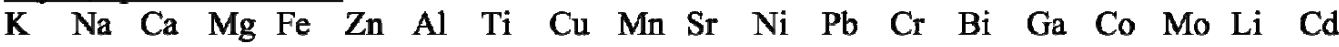

Рис. 2. Распределение металлов (в порядке убывания их концентраций) в мышечных тканях рыб Красноярского водохранилища (* - ниже предела обнаружения)

Fig. 2. The distribution of metals (in descending order of concentrations) in the muscle tissue of fishes from the Krasnoyarsk reservoir $(*-$ below the detection limit) 
Содержание калия, магния и кальция было выше в белой мускулатуре (за исключением щуки); натрий в большей степени концентрировался в красной мускулатуре. Для трех микроэлементов установлено достоверно более высокое содержание в красных мышцах по сравнению с белыми: в 2 раза (Zn), 3-5 раз $(\mathrm{Fe})$ и 5-7 раз $(\mathrm{Cu})$. Содержание кобальта и лития у всех рыб было выше в красной мускулатуре, но различия были достоверны только у одного из изученных видов. Тенденция, хотя и недостоверная, большего накопления $\mathrm{Al}, \mathrm{Cd}, \mathrm{Mn}, \mathrm{Ni}$, Ti в красной мускулатуре по сравнению с белой была выявлена у всех трех видов рыб. Из всех исследованных тяжелых металлов не удалось обнаружить ни одного элемента, содержание которого было бы выше в белой мускулатуре у всех рыб. Различия в содержании некоторых металлов, а именно свинца и стронция, имели видоспецифичный характер, т.е. данные металлы в большей степени накапливались в красных либо белых мышцах в зависимости от вида рыб.

\section{Обсуждение результатов}

Полученные результаты свидетельствуют о принципиальных различиях в накоплении некоторых металлов ( $\mathrm{Na}, \mathrm{K}, \mathrm{Ca}, \mathrm{Mg}, \mathrm{Cu}$, $\mathrm{Fe}, \mathrm{Zn}$ ), относящихся к макро- и микроэлементам, разными мышечными тканями пресноводных рыб. Особенности их распределения, очевидно, отражают фундаментальные различия в функционировании красной и белой мускулатуры, поскольку все они относятся к эссенциальным элементам. Оценка содержания неэссенциальных элементов (металлов) в мускулатуре рыб Красноярского водохранилища не выявила статистически значимых различий между двумя типами мышечной ткани. Тем не менее, с учетом отмеченных тенденций к более интенсивному накоплению в красной мускулатуре данной группы элементов, особенно опасных экотоксикантов $(\mathrm{Pb}, \mathrm{Cd})$, проверка гипотезы об их избирательном накоплении разными видами тканей требует дальнейших исследований. Отметим, что район исследования не имеет точечных источников загрязнения и в рамках данной работы рассматривается как фоновый.

Данные о распределении металловмакроэлементов ( $\mathrm{Na}, \mathrm{K}, \mathrm{Ca}, \mathrm{Mg})$ в красных и белых мышцах получены ранее только для морских рыб. В большей части работ авторами не были выявлены достоверные различия по этим элементам (Thurston, MacMaster, 1960; Joseph, 1967; Ashoka et al., 2011). В ряде случаев обнаружены исключения для каждого из указанных металлов, однако их соотношение в двух типах мускулатуры редко превышало 1:2 (Goldberg, 1962; Karunarathna, Attygalle, 2009; Albrecht-Ruiz, Salas-Maldonado, 2015). При этом тот или иной элемент мог преобладать как в красной, так и в белой мускулатуре (Goldberg, 1962; Karunarathna, Attygalle, 2009; Albrecht-Ruiz, Salas-Maldonado, 2015). Характерным примером противоречивости данных по макроэлементам являются результаты исследования малого восточного тунца Euthynnus affinis (Cantor, 1849). Так, в работе Mukundan et al. (1979) химический состав мускулатуры данного вида характеризуется преобладанием калия в красной мускулатуpe, в то время как Karunarathna и Attygalle (2009) отмечают преобладание указанного металла в белой мускулатуре. В исследованных нами видах пресноводных рыб Красноярского водохранилища $\mathrm{K}$ преобладает в белой мускулатуре, тогда как $\mathrm{Na}$ - в красной, при этом статистически достоверные отличия отмечены для плотвы и леща по калию, для леща и щуки по натрию (табл. 2). Более последовательны данные по содержанию в 


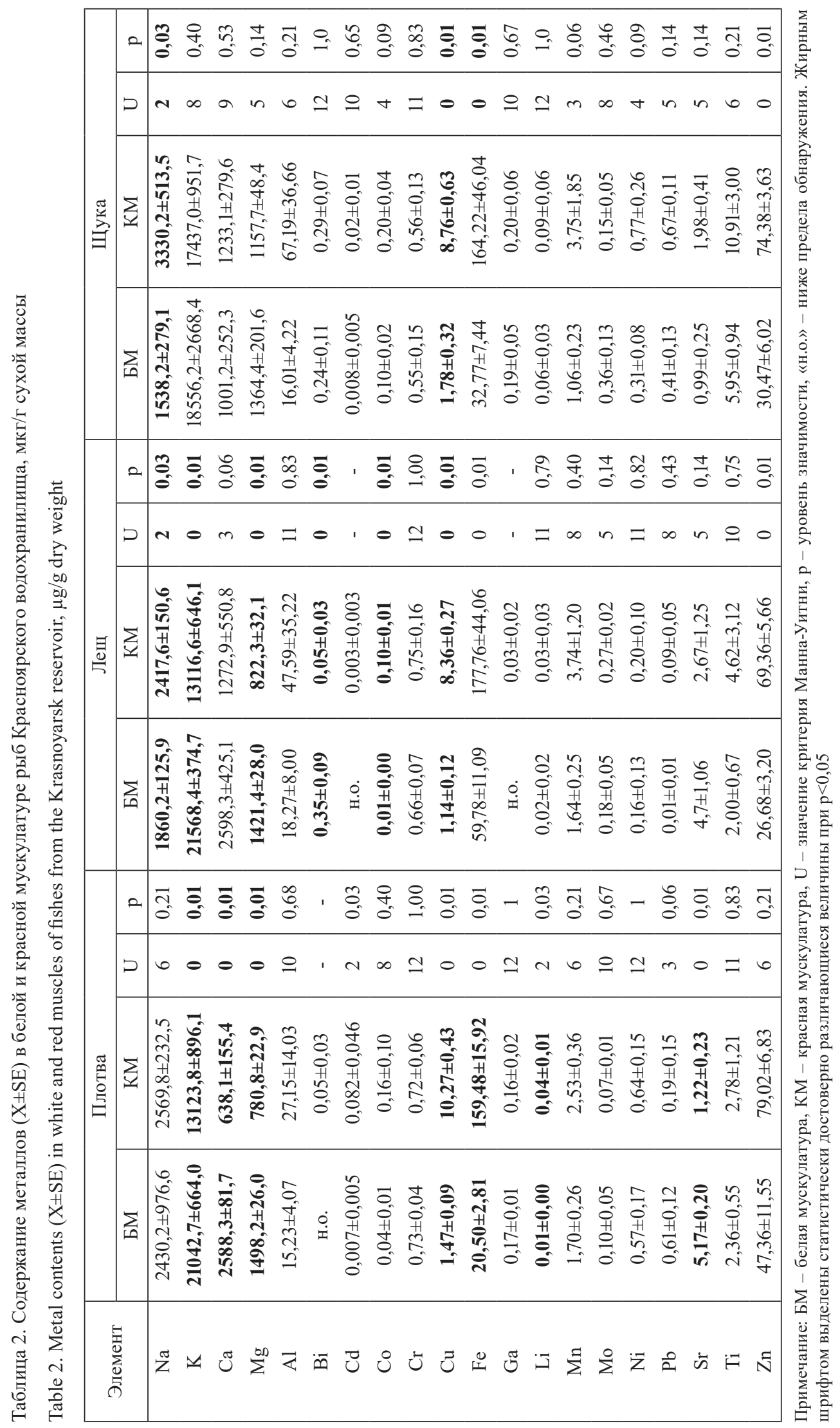


мускулатуре магния. В опубликованных работах содержание данного металла, как правило, одинаково для двух типов мускулатуры (Goldberg, 1962; Karunarathna, Attygalle, 2009; Ashoka et al., 2011) либо незначительно выше в белой мускулатуре (не более чем в два раза) (Karunarathna, Attygalle, 2009; Albrecht-Ruiz, Salas-Maldonado, 2015). У изученных пресноводных видов рыб Красноярского водохранилища отмечено более высокое содержание магния в белой мускулатуре (табл. 2).

Содержание железа в красной мускулатуре рыб Красноярского водохранилища в 3-5 раз превышало его содержание в белой мускулатуре. Данный факт связан, главным образом, с высоким содержанием железосодержащих белков - миоглобина и гемоглобина (Moyle et al., 2004; Ashoka et al., 2011). Полученные нами данные о распределении железа в мышечных тканях соответствуют сведениям из ранее опубликованных работ (Fujikawa, Naganuma, 1936; Alexander, 1955; Лисовская, Петкевич, 1968; Малькольм Лав, 1976). Впервые повышенное содержание железа в красной мускулатуре было косвенно отмечено в работе Peterson, Elvehjem (1928). Однако авторы данной работы определяли содержание $\mathrm{Fe}$ во всем объеме скелетной мускулатуры, впоследствии выделяя рыб, имеющих более темное и более светлое мясо. В дальнейшем содержание железа уже в дифференцированных типах мускулатуры было определено у poxy Labeo rohita (Hamilton, 1822), дальневосточной сельди Sardinops sagax melanosticta (Temminck \& Schlegel, 1846), крапчатого аргуca Scatophagus argus (Linnaeus, 1766), хамсы Engraulis encrasicolus (Linnaeus, 1758), черноморской сельди Alosa immaculata Bennett, 1835 и других представителей морской и пресноводной ихтиофауны (Fujikawa, Naganuma, 1936; Alexander, 1955; Лисовская, Петкевич, 1968; Малькольм Лав, 1976). При этом соот- ношение концентраций железа в красной и белой мускулатуре у пресноводных видов составляет 2:1-6:1, у морских в среднем 2:1-8:1 (табл. 3). Исключение - перуанский анчоус Engraulis ringens Jenyns, 1842, содержание железа в красной мускулатуре которого более чем в 20 раз превышает содержание в белой (Albrecht-Ruiz, Salas-Maldonado, 2015).

Содержание меди в красной мускулатуpe большинства видов рыб также превышало таковое в белой. Исключение составляют клариевый сом и скумбриевидный тунец Auxis rochei (Risso, 1810) (Karunarathna, Attygalle, 2009; Chaijan et al., 2013). В мускулатуре представителей ихтиофауны Красноярского водохранилища содержание меди в красных мышцах было в 5-7 раз выше, чем в белых. Согласно имеющимся в литературе данным, соотношение содержания меди в красной и белой мускулатуре варьирует в значительной степени (от 2:1 до 80:1) как у морских, так и у пресноводных видов.

Содержание цинка, как правило, выше в красной мускулатуре. Соотношение концентраций данного элемента в двух типах мышечной ткани не превышает 6:1 и, по-видимому, не имеет различий у морских и пресноводных видов рыб. Исключение из этой закономерности демонстрируют морские виды Thunnus albacares (Bonnaterre, 1788) и Liza saliens (Risso, 1810), белая мускулатура которых содержит в 1,5 раза больше цинка, чем красная (Goldberg, 1962; Ebrahimzadeh et al., 2011).

Различия в содержании меди и цинка в двух типах мускулатуры ряд авторов связывает со специфичным составом белков и ферментов, предполагая важное биологическое значение высоких концентраций этих металлов в красной мускулатуре (Carpene et al., 1990, 1998). Также различие в содержании указанных элементов в красной и белой мускулатуре может быть обусловлено раз- 


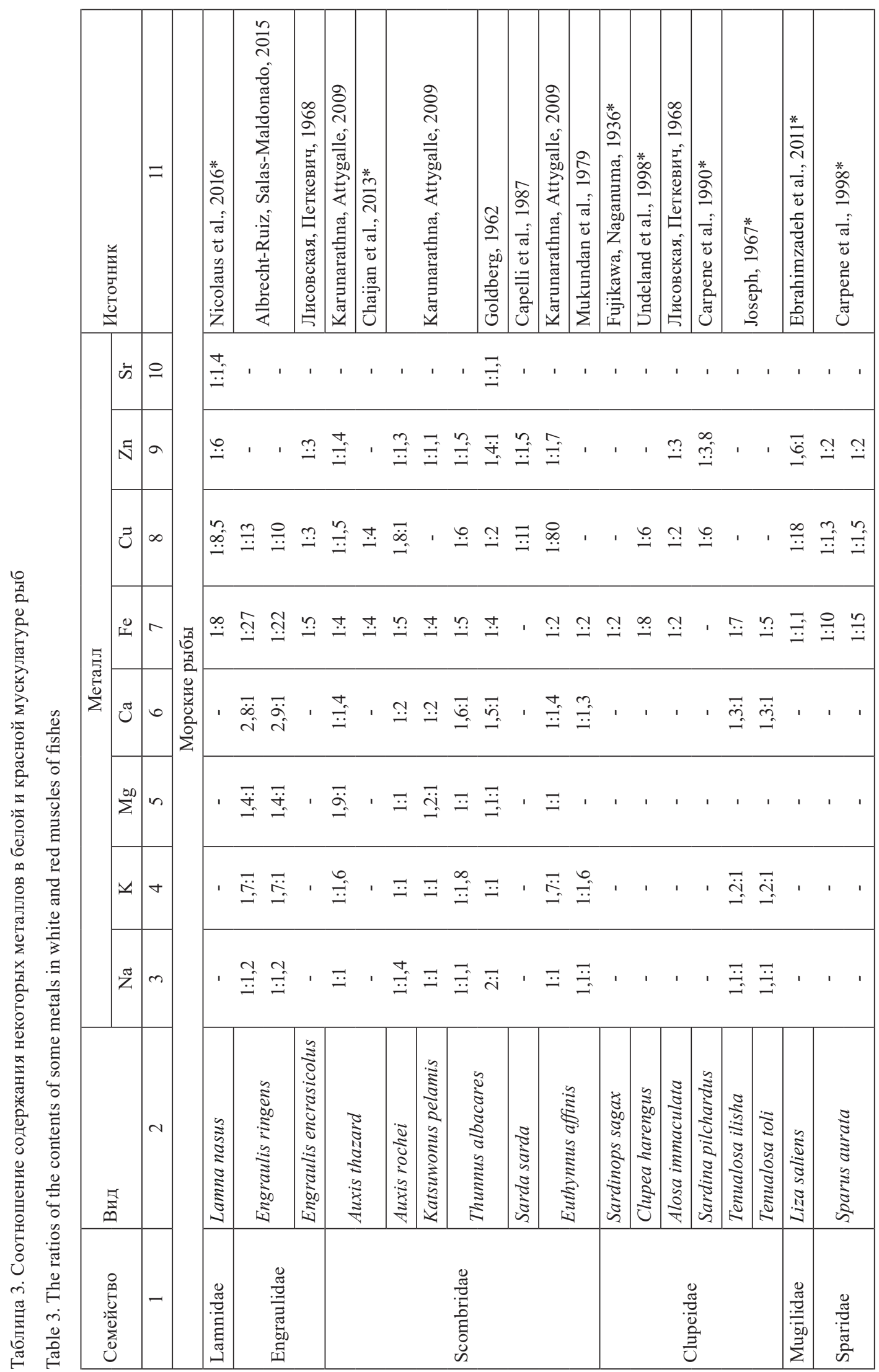




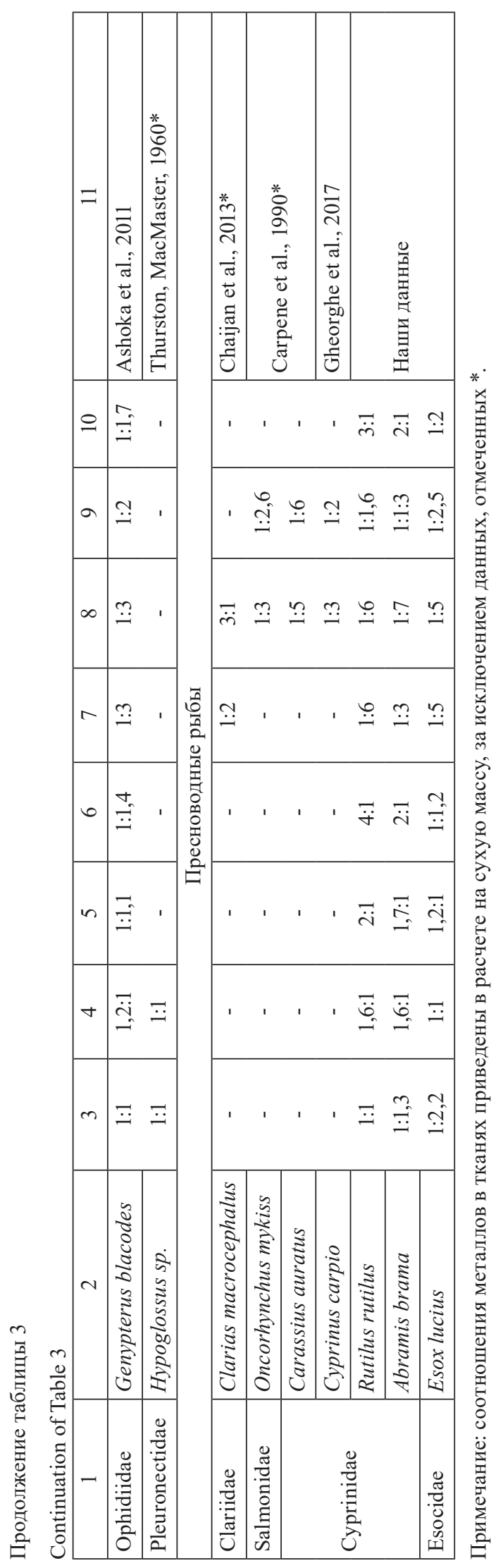


витой сетью капилляров в красной мускулатуре (Moyle et al., 2004). Эритроциты и плазма крови рыб, как правило, характеризуются высоким содержанием медь- и цинксодержащих ферментов - церрулоплазмина, карбоангидразы, оксидоредуктазы и др. (Мур, Рамамурти, 1987; Bury, Grosell, 2003; Esbaugh et al., 2004; Янович, Янович, 2014). Следует отметить, что медь, как и железо, относится к прооксидантным металлам. Соответственно, чем выше содержание данного металла в мышечной ткани, тем интенсивнее происходит окисление липидов в этом типе мускулатуры (Undeland et al., 1998; Chaijan et al., 2013).

Распределение стронция в двух типах осевой мускулатуры изучено в меньшей степени и представлено в работах Nicolaus et al. (2016), Ashoka et al. (2011) и Goldberg (1962), при этом во всех случаях количество стронция в красной мускулатуре было выше, чем в белой. Исследования названных авторов проведены исключительно на морских видах рыб. В нашей работе у плотвы отмечено достоверно более высокое содержание стронция в белой мускулатуре. Стронций известен своей способностью замещать кальций в физиологических процессах организмов. Коэффициент накопления $\mathrm{Sr}$ у пресноводных рыб выше, чем у морских, так как содержание стронция в организме рыб обратно пропорционально содержанию кальция в воде. Хищ- ные рыбы обычно характеризуются более низким уровнем содержания стронция (Wood et al., 2012b). Высокое содержание кобальта в красной мускулатуре леща и щуки из Красноярского водохранилища, по-видимому, объясняется повышенным содержанием витамина $\mathrm{B}_{12}$ В данном типе мышечной ткани (Brækkan, 1956).

\section{Заключение}

В результате проведенных исследований выявлены значимые различия между красной и белой осевой мускулатурой трех пресноводных видов рыб по содержанию $\mathrm{Na}, \mathrm{K}, \mathrm{Ca}, \mathrm{Mg}$, $\mathrm{Cu}, \mathrm{Fe}, \mathrm{Zn}$. Различия в распределении микроэлементов (Cu, Fe, $\mathrm{Zn}$ ) аналогичны таковым у морских рыб и связаны с особенностями функционирования красной и белой мускулатуры. Распределение макроэлементов (Na, $\mathrm{K}, \mathrm{Ca}, \mathrm{Mg}$ ) в разных типах мышечной ткани, впервые полученное для пресноводных рыб, имело относительно похожий характер для всех исследованных видов (плотва, лещ, щука). Содержание калия, магния и кальция (за исключением щуки) было выше в белой мускулатуре; $\mathrm{Na}$ в большей степени концентрировался в красной мускулатуре. Оценка возможности избирательного накопления опасных, неэссенциальных металлов красной мускулатурой требует дополнительных исследований в условиях загрязненных вод или в эксперименте.

\section{Благодарности / Acknowledgements}

Работа выполнена в рамках Государственного задания Министерства образования и науки Российской Федерации Сибирскому федеральному университету на 2017 год (проект № 6.1504.2017/4.6 «Водные и амфибионтные животные как вектор переноса полиненасыщенных жирных кислот в наземные экосистемы и к человеку»).

This study was carried out as part of the State Assignment of the Ministry of Education and Science of the Russian Federation (project No. 6.1504.2017 / 4.6 "Aquatic and amphibiotic animals as carriers of polyunsaturated fatty acids in natural ecosystems and to humans"). 


\section{Список литературы / References}

Красноярское водохранилище: мониторинг, биота, качество вод (2008) Красноярск, Сибирский федеральный университет, 538 с. [Krasnoyarsk water reservoir: monitoring, biota, water quality (2008) Krasnoyarsk, Siberian Federal University, 538 p. (in Russian)]

Лисовская В.И., Петкевич Т.А. (1968) Биохимический состав мышц некоторых черноморских рыб. Рыбное хозяйство, 9: 65-66 [Lisovskaya V.I., Petkevich T.A. (1968) Biochemical composition of the muscles of some fishes of the Black Sea. Fisheries [Rybnoe hozyaystvo], 9: 65-66 (in Russian)]

Малькольм Лав Р. (1976) Химическая биология рыб. М., Пищевая промышленность, 349 с. [Malcolm Love R. (1976) The chemical biology of fishes. Moscow, Pishchevaya promyshlennost, 349 p. (in Russian)]

Марченко А.Л., Христофорова Н.К., Чернова Е.Н. (2006) Содержание тяжелых металлов в мышцах красноперок Южного Приморья. Известия ТИНРО, 146: 276-282 [Marchenko A.L., Khristoforova N.K., Chernova E.N. (2006) Content of heavy metals in muscles of eastern redfins in the southern Primorye. Transactions of the Pacific Research Institute of Fisheries and Oceanography [Izvestiya TINRO], 146: 276-282 (in Russian)]

Мур Д.В., Рамамурти С. (1987) Тяжелье металль в природных водах. М., Мир, 287 с. [Moore J.W., Ramamoorthy S. (1987) Heavy metals in natural waters. Moscow, Mir, 287 p. (in Russian)]

Патин С.А., Морозов Н.П. (1981) Микроэлементы в морских организмах и экосистемах. М., Легкая и пищевая промышленность, 152 с. [Patin S.A., Morozov N.P. (1981) Trace elements in marine organisms and ecosystems. Moscow, Legkaya i pishchevaya promyshlennost, 152 p. (in Russian)]

Янович Н.Е., Янович Д.О. (2014) Роль микроэлементов в жизнедеятельности прудовых рыб. Науковий вісник Львівського наџіонального університету ветеринарної медицини та біотехнологій імені С.3. Гжииького, 16 (2.2): 345-372 [Yanovych N.E., Yanovych D.O. (2014) Trace elements role in pond fishes vital functions. Scientific Messenger of LNU of Veterinary Medicine and Biotechnologies, 16 (2.2): 345-372 (in Ukrainian)]

Albrecht-Ruiz M., Salas-Maldonado A. (2015) Chemical composition of light and dark muscle of Peruvian anchovy (Engraulis ringens) and its seasonal variation. Journal of Aquatic Food Product Technology, 24 (2): 191-196

Alexander K.M. (1955) A comparison of the gross chemical composition of the red and white muscles in the two fishes, Scatophagus argus and Labeo rohita. Journal of Animal Morphology and Physiology, 1: 58-61

Anishchenko O.V., Sushchik N.N., Makhutova O.N., Kalachova G.S., Gribovskaya I.V., Morgun V.N., Gladyshev M.I. (2017) Benefit-risk ratio of canned pacific saury (Cololabis saira) intake: essential fatty acids vs. heavy metals. Food and Chemical Toxicology, 101: 8-14

Ashoka S., Peake B.M., Bremner G., Hageman K.J. (2011) Distribution of trace metals in a ling (Genypterus blacodes) fish fillet. Food Chemistry, 125 (2): $402-409$

Bone Q. (1978) Locomotor muscle. Fish Physiology. Volume 7. Hoar W.S., Randall D.J. (eds.) New York, Academic Press, p. 361-424

Bosch A.C., O’Neill B., Sigge G.O., Kerwath S.E., Hoffman L.C. (2016a) Heavy metals in marine fish meat and consumer health: a review. Journal of the Science of Food and Agriculture, 96(1): 32-48 
Bosch A.C., O’Neill B., Sigge G.O., Kerwath S.E., Hoffman L.C. (2016b) Mercury accumulation in Yellowfin tuna (Thunnus albacares) with regards to muscle type, muscle position and fish size. Food Chemistry, 190: 351-356

Brækkan O.R. (1956) Function of the red muscle in fish. Nature, 178 (4536): 747-748

Bury N., Grosell M. (2003) Iron acquisition by teleost fish. Comparative Biochemistry and Physiology Part C: Toxicology \& Pharmacology, 135 (2): 97-105

Capelli R., Minganti V., Bernhard M. (1987) Total mercury, organic mercury, copper, manganese, selenium, and zinc in Sarda sarda from the gulf of Genoa. Science of the Total Environment, 63: 83-99

Carpene E., Cattani O., Serrazanetti G.P., Fedrizzi G., Cortesi P. (1990) Zinc and copper in fish from natural waters and rearing ponds in Northern Italy. Journal of Fish Biology, 37 (2): 293-299

Carpene E., Martin B., Dalla Libera L. (1998) Biochemical differences in lateral muscle of wild and farmed gilthead sea bream (series Sparus aurata L.). Fish Physiology and Biochemistry, 19 (3): 229-238

Chaijan M., Klomklao S., Benjakul S. (2013) Characterisation of muscles from Frigate mackerel (Auxis thazard) and catfish (Clarias macrocephalus). Food Chemistry, 139(1-4): 414-419

Cheung K.C., Leung H.M., Wong M.H. (2008) Metal concentrations of common freshwater and marine fish from the Pearl River Delta, South China. Archives of Environmental Contamination and Toxicology, 54 (4): 705-715

Cronin M., Davies I.M., Newton A., Pirie J.M., Topping G., Swan S. (1998) Trace metal concentrations in deep sea fish from the North Atlantic. Marine Environmental Research, 45 (3): 225-238

Ebrahimzadeh M.A., Eslami S., Nabavi S.F., Nabavi S.M. (2011) Determination of trace element level in different tissues of the leaping mullet (Liza saliens, Mugilidae) collected from Caspian Sea. Biological Trace Element Research, 144(1-3): 804-811

Esbaugh A.J., Lund S.G., Tufts B.L. (2004) Comparative physiology and molecular analysis of carbonic anhydrase from the red blood cells of teleost fish. Journal of Comparative Physiology BBiochemical Systemic and Environmental Physiology, 174(5): 429-438

Fujikawa K., Naganuma H. (1936) Chemical composition of sardine, Sardinia melanosticta (C and V) from Tyosen. 1. Comparative study on dark muscle and white muscle. Bulletin of the Japanese Society of Scientific Fisheries, 5: 95-102

Gheorghe S., Vasile G., Gligor C., Lucaciu I.E., Nita-Lazar M. (2017) Metallic elements (Cu, $\mathrm{Zn}, \mathrm{Ni}$ and $\mathrm{Mn}$ ) toxicity effects determination on a fresh water fish Cyprinus carpio (common carp) laboratory acclimatized. Revista de Chimie, 68 (8): 1711-1715

Goldberg E.D. (1962) Elemental composition of some pelagic fishes. Limnology and Oceanography, 7: $72-75$

Golovanova I.L. (2008) Effects of heavy metals on the physiological and biochemical status of fishes and aquatic invertebrates. Inland Water Biology, 1(1): 93-101

Hammer Ø., Harper D.A.T., Ryan P.D. (2001) PAST: Paleontological statistics software package for education and data analysis. Palaeontologia Electronica, 4(1): 4

Johnston I.A. (1981) Structure and function of fish muscle. Symposia of the Zoological Society of London, 48: 71-113

Joseph M.M. (1967) A histophysiological study of the red and white muscles of a migratory Hilsa ilish a and a non-migratory Hilsa toli fish. PhD thesis, University of Baroda, Baroda, India, $197 \mathrm{p}$. 
Karunarathna K.A.A.U., Attygalle M.V.E. (2009) Mineral spectrum in different body parts of five species of tuna consumed in Sri Lanka. Vidyodaya Journal of Science, 14 (2): 103-111

Kojadinovic J., Potier M., Le Corre M., Cosson R.P., Bustamante P. (2007) Bioaccumulation of trace elements in pelagic fish from the Western Indian Ocean. Environmental Pollution, 146(2): 548566

Luther P.K., Munro P.M.G., Squire J.M. (1995) Muscle ultrastructure in the teleost fish. Micron, 26(5): 431-459

Moyle P.B., Cech J.J. (2004) Fishes: an introduction to ichthyology. 5th Edition. Prentice-Hall, Upper Saddle River, 590 p.

Mukundan M.K., Arul James M., Radhakrishnan A.G., Antony P.D. (1979) Red and white meat of tuna (Euthynnus affinis). Their biochemical role and nutritional quality. Fishing Technology, 16: $77-82$

Nicolaus E.E.M., Bendall V.A., Bolam T.P.C., Maes T., Ellis J.R. (2016) Concentrations of mercury and other trace elements in porbeagle shark Lamna nasus. Marine Pollution Bulletin, 112(1-2): 406410

Parks T.B., Rose E.R. (1933) The copper, iron, and manganese content of fish. The Journal of Nutrition, 6 (1): 95-98

Peña-Icart M., Rodrigues Pereira-Filho E., Lopes Fialho L., Nóbrega J.A., Alonso-Hernández C., Bolaños-Alvarez Y., Muñoz-Caravaca A., Pomares-Alfonso M.S. (2017) Study of macro and microelements in fish from the Cienfuegos Bay. Relationship with its content in sediments. Environmental Monitoring and Assessment, 189(9): 427

Peterson W.H., Elvehjem C.A. (1928) The iron content of plant and animal foods. Journal of Biological Chemistry, 78: 215-223

Sanger A.M., Stoiber W. (2001) Muscle fiber diversity and plasticity. Fish physiology: muscle development and growth. Johnston I.A. (ed.) Academic Press, San Diego, San Francisco, New York, Boston, London, Sydney, Tokyo, p. 187-250

Svendsen J.C., Tirsgaard B., Cordero G.A., Steffensen J.F. (2015) Intraspecific variation in aerobic and anaerobic locomotion: gilthead sea bream (Sparus aurata) and Trinidadian guppy (Poecilia reticulata) do not exhibit a trade-off between maximum sustained swimming speed and minimum cost of transport. Frontiers in Physiology, 6: 43

Thurston C.E., MacMaster P.P. (1960) Variations in chemical composition of different parts of halibut flesh. Food Research, 25(2): 229-236

Undeland I., Ekstrand B., Lingnert H. (1998) Lipid oxidation in herring (Clupea harengus) light muscle, dark muscle, and skin, stored separately or as intact fillets. Journal of the American Oil Chemists' Society, 75 (5): 581-590

Underwood W., Anthony R., Gwaltney-Brant S., Poison A.S.P.C.A., Meyer R. (2013) AVMA guidelines for the euthanasia of animals. American Veterinary Medical Association, Schaumburg, IL, USA, $102 \mathrm{p}$.

Wood C.M., Farrell A.P., Brauner C.J. (2012a) Homeostasis and toxicology of essential metals. Fish physiology, Volume 31 A. Academic Press, 509 p.

Wood C.M., Farrell A.P., Brauner C.J. (2012b) Homeostasis and toxicology of non-essential metals. Fish physiology, Volume 31 B. Academic Press, 500 p. 